\title{
Synchrony between Early Jurassic extinction, oceanic anoxic event, and the Karoo-Ferrar flood basalt volcanism
}

\author{
József Pálfy Department of Geology and Paleontology, Hungarian Natural History Museum, H-1431 Budapest, Hungary \\ Paul L. Smith Department of Earth and Ocean Sciences, University of British Columbia, Vancouver, British Columbia V6T 1Z4, Canada
}

\begin{abstract}
A well-known second-order mass extinction took place during the Pliensbachian and Toarcian Stages of the Early Jurassic. First recognized as a minor Pliensbachian peak in the global extinction rate, it has alternatively been interpreted as a regional response to the early Toarcian oceanic anoxic event. Detailed studies established it as a global long-term event spanning five successive ammonoid zones. Here we present a revised time scale based on highprecision $\mathrm{U}-\mathrm{Pb}$ ages resolved to the zone level, which suggests that elevated extinction rates were sustained for about $4 \mathrm{~m} . \mathrm{y}$. and peak extinction occurred at $183 \mathrm{Ma}$. Recent isotopic dating of flood basalts from the southern Gondwanan Karoo and Ferrar provinces documents a culmination in volcanic activity ca. $183 \mathrm{Ma}$. The onset of volcanism is recorded as an inflection and start of a rapid rise of the seawater ${ }^{87} \mathrm{Sr} /{ }^{86} \mathrm{Sr}$ curve. The synchrony of voluminous flood basalt eruptions and biotic crises, as already noted for three of the major mass extinctions, permits a causal relationship, which in this case may be mediated by widespread oceanic anoxia.
\end{abstract}

Keywords: extinction, Toarcian, flood basalt, oceanic anoxic event, time scale.

\section{INTRODUCTION}

The ultimate causes or chain of events triggering mass extinctions are difficult to study but of fundamental scientific interest. Extraterrestrial impacts, climate changes, sea-level changes, oceanic anoxia, and flood basalt volcanism are some of the most often cited possible triggers for elevated extinction rates or wholesale ecosystem collapse. In all instances, hypotheses can be properly tested only if precise timing and correlation of events are possible. A second-order extinction event involving several marine groups occurred in Early Jurassic time (Hallam, 1986). There is a well-established connection between this extinction and a period of oceanic anoxia, which in turn appears to be related to a significant sea-level rise (Jenkyns, 1988; Hallam, 1997). However, some workers argue that either extraterrestrial impacts or flood basalt volcanism were the prime causes of many or all extinctions, on the basis of their mutual periodicity and some well-established cases of synchrony (Raup and Sepkoski, 1984; Rampino and Stothers, 1988; Stothers, 1993).

Herein we discuss the temporal relationship between the Early Jurassic extinction and volcanism in the Karoo and Ferrar large igneous provinces of southern Gondwana. A possible causal link has been tentatively proposed before, but large uncertainties in the Early Jurassic time scale and inaccuracies in dating the magmatism hindered the testing of this hypothesis (Courtillot, 1994). We review paleontological data pertaining to the Early Jurassic extinction, summarize recent advances in dating the Karoo and Ferrar igneous rocks, assess the temporal relationship between extinction and volcanism in the context of a newly revised, zonally resolved time scale for the critical Pliensbachian-Toarcian interval, examine the geochemical evidence for the oceanic anoxic event and environmental change, and discuss some possible extinction scenarios and relationships of the Early Jurassic events.

\section{EARLY JURASSIC EXTINCTION}

An Early Jurassic (Pliensbachian) extinction event was recognized from a global database of the stratigraphic ranges of marine animal families and genera. Of lesser scale than the celebrated "Big Five" (i.e., the five greatest extinction events recognized), this extinction, in which about 5\% of families were lost, was nonetheless a significant event (Raup and Sepkoski, 1984). An independent compilation of fossil families detected as much as $5 \%$ marine extinction in both the Pliensbachian and Toarcian, and 2.4\%-12.8\% extinction among continental organisms in the Toarcian (Benton, 1995). On the basis of detailed analysis of the fossil record of northwest European epicontinental seas, Hallam $(1986,1996)$ regarded the extinction as a regional event, the later phase of which coincided with widespread anoxia in the early Toarcian (Fig. 1D). The recognition of an oceanic anoxic event in the Falciferum Zone (Jenkyns, 1988) provided an extinction mechanism that could inflict losses on marine biota by the spread of the oxygen-deficient bottom waters. Little and Benton (1995) analyzed the time distribution of global family extinctions and found that a protracted interval of five zones spanning the Pliensbachian-Toarcian stage boundary showed elevated extinction levels (Fig. 1C). However, outcrop-scale studies of the most fossiliferous sections in England and Ger- many displayed a clear species extinction peak correlating with the anoxic event in the Falciferum Zone (Little, 1996). The global extent of the Pliensbachian-Toarcian extinction event was established through detailed studies in the Andean basin (Aberhan and Fürsich, 1997) and deepwater facies of the western Tethys (Vörös, 1993) and Japan (Hori, 1993).

\section{AGE OF KAROO AND FERRAR IGNEOUS PROVINCES}

The Karoo province in South Africa and the Ferrar province in Antarctica are disjunct parts of a once contiguous large igneous province of Jurassic age in Gondwana. It ranks among the most voluminous flood basalt provinces of the Phanerozoic (Rampino and Stothers, 1988). Early radiometric dating, relying on the $\mathrm{K}-\mathrm{Ar}$ method, was plagued with problems. A suite of whole-rock ages for the Karoo Group is distributed between 135 and $225 \mathrm{Ma}$, with apparent peaks of volcanic intensity at $193 \pm 5$ and $178 \pm$ $5 \mathrm{Ma}$ (Fitch and Miller, 1984). The K-Ar chronometer often yields anomalously young or old ages in disturbed systems, due to Ar loss or uptake of excess Ar, respectively. The use of ${ }^{40} \mathrm{Ar}-{ }^{39} \mathrm{Ar}$ and $\mathrm{U}-\mathrm{Pb}$ dating, however, permits reliable determination of the true crystallization age of mafic igneous rocks. For valid comparison between dates recently obtained using different isotopic methods, we recalculated the published ages to reflect external errors (i.e., including decay constant uncertainty) at the $2 \sigma$ level and the currently accepted ages of standards for ${ }^{40} \mathrm{Ar}-{ }^{39} \mathrm{Ar}$ dating (Renne et al., 1998). ${ }^{1}$

Duncan et al. (1997) reported 28 precise ${ }^{40} \mathrm{Ar}-{ }^{39} \mathrm{Ar}$ plateau ages from Karoo Group basalts and dolerites in South Africa and Namibia. The ages range between 179 and $186 \mathrm{Ma}$, the majority being at $183 \pm 2 \mathrm{Ma}$ (Fig. 1E). A U-Pb age of $183.7 \pm 1.9$ Ma obtained by Encarnación et al. (1996) from a tholeiitic sheet in South Africa is in good agreement with the ${ }^{40} \mathrm{Ar}-{ }^{39} \mathrm{Ar}$ results (Fig. 1E).

Various units within the Ferrar Group in Antarctica have also been dated (Fig. 1F). From the Kirkpatrick Basalt, Foland et al. (1993)

${ }^{1}$ GSA Data Repository item 200080, Table 2, Recalculation of published radiometric ages for Karoo and Ferrar Groups, is available on request from Documents Secretary, GSA, P.O. Box 9140, Boulder, CO 80301-9140, editing@geosociety.org, or at www.geosociety.org/pubs/ft2000.htm.

Data Repository item 200080 contains additional material related to this article. 


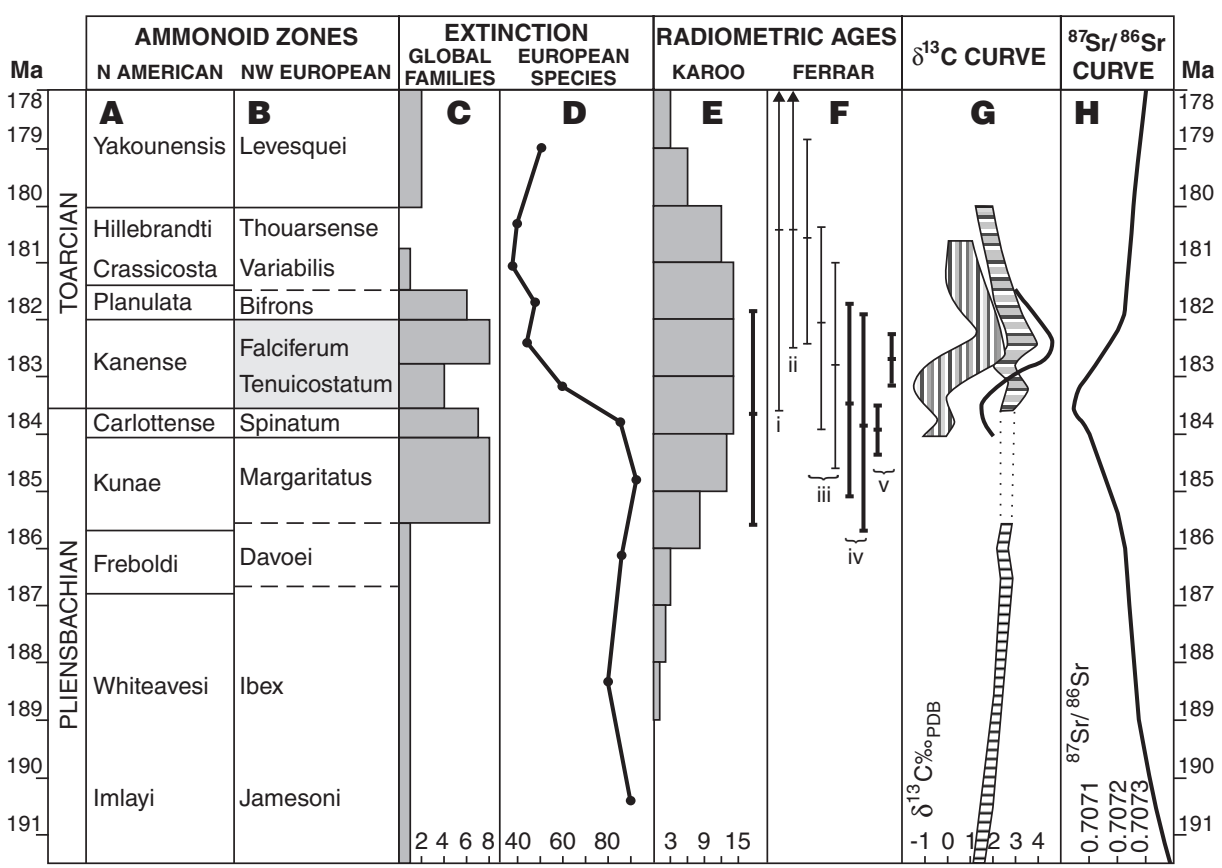

Figure 1. Correlation of marine extinction event, Karoo and Ferrar flood basalt volcanism, and carbon and strontium isotope stratigraphy in numerically calibrated ammonoid zonal chronostratigraphic framework. A: North American regional standard ammonoid zonation (Pliensbachian, Smith et al., 1988; Toarcian, Jakobs et al., 1994); lack of horizontal line between zones indicates that no numeric estimate is available for zone boundary. B: Northwest European standard ammonoid zonation; shading indicates extent of organic-rich deposits in Tenuicostatum and Falciferum zones in western Tethys and northwest Europe. C: Number of global family extinctions by zone (Little and Benton, 1995). D: Cumulative species diversity per zone, expressed in number of species of bivalves, ammonoids, rhynchonellid brachiopods, crinoids, foraminifera, and ostracods from Britain (Hallam, 1996). E: Radiometric ages from Karoo Group (recalculated from published sources with corrected standard ages for ${ }^{40} \mathrm{Ar}-{ }^{39} \mathrm{Ar}$ geochronology and $2 \sigma$ external errors, unless indicated otherwise) for valid comparison (Renne et al., 1998); age spectrum histogram of $28{ }^{40} \mathrm{Ar}-{ }^{39} \mathrm{Ar}$ dates with $1 \sigma$ internal errors (Duncan et al., 1997) and error bar of U-Pb age (Encarnación et al., 1996). F: ${ }^{40} \mathrm{Ar}-{ }^{39} \mathrm{Ar}$ and U-Pb (heavy lines) ages from Ferrar Group (recalculated from published sources with corrected standard ages for ${ }^{40} \mathrm{Ar}-{ }^{39} \mathrm{Ar}$ geochronology and $2 \sigma$ external errors for valid comparison (Renne et al., 1998). Error bars from left to right: i, composite of $11{ }^{40} \mathrm{Ar}-{ }^{39} \mathrm{Ar}$ ages by Heimann et al. (1994); ii, composite of two ${ }^{40} \mathrm{Ar}-{ }^{39} \mathrm{Ar}$ ages by Foland et al. (1993); iii, three ${ }^{40} \mathrm{Ar}-{ }^{39} \mathrm{Ar}$ ages by Duncan et al. (1997); iv, two U-Pb ages by Encarnación et al. (1996); and v, two U-Pb ages by Minor and Mukasa (1997). G: Carbon isotope profiles: horizontal rule-composite profile from Central Apennines, Italy (E. Morettini, 1999, personal commun.); vertical rule-Dorset, England (Jenkyns and Clayton, 1997); solid line-composite curve from Tethyan sections (Jenkyns et al., 1991). H: Seawater ${ }^{87} \mathrm{Sr} /{ }^{86} \mathrm{Sr}$ curve simplified from Jones et al. (1994); monotonous decline of curve starts in Hettangian from values $>0.7077$.

reported two nearly identical incremental heating ${ }^{40} \mathrm{Ar}-{ }^{39} \mathrm{Ar}$ ages of $180.4 \pm 2.1 \mathrm{Ma}$. Heimann et al. (1994) reported $11{ }^{40} \mathrm{Ar}-{ }^{39} \mathrm{Ar}$ plateau ages from the Kirkpatrick Basalt that form a tight cluster and permit a composite age determination of $180.3 \pm 3.6 \mathrm{Ma}$. Basalts from the Kirwan Mountains, East Antarctica, yielded ${ }^{40} \mathrm{Ar}-{ }^{39} \mathrm{Ar}$ plateau ages of $180.6 \pm 1.8,182.7 \pm 1.8$, and $182.8 \pm$ $1.8 \mathrm{Ma}$ (Duncan et al., 1997). Concordant U-Pb ages of $183.4 \pm 1.9$ and $183.8 \pm 1.9$ were obtained by Encarnación et al. (1996) from sills within the Ferrar Group. Minor and Mukasa (1997) dated (U-Pb) two samples from the Dufek intrusion (which forms part of the Ferrar Group) as $183.9 \pm 0.4$ and $182.7 \pm 0.5 \mathrm{Ma}$.

These radiometric ages suggest a short-lived magmatic episode, represented by coeval rocks of the Karoo and Ferrar Groups. Such brevity of vol-
1990) and $189.6 \pm 4.0$ (Gradstein et al., 1994). We constructed a revised Jurassic time scale, using several recently obtained $\mathrm{U}-\mathrm{Pb}$ ages from volcanic layers that are also dated by ammonoid biochronology in the North American Cordillera, and additional $\mathrm{U}-\mathrm{Pb}$ dates compiled from recent reports (Pálfy et al., 2000b). The density and biochronologic resolution of the isotopic age database across the Pliensbachian-Toarcian transition allows, for the first time, the estimation of zonal boundary ages for six consecutive zones. None of the 14 relevant isotopic ages listed in Table 1 were used in earlier time scales. Zonal boundary ages are calculated using the chronogram method (Harland et al., 1990), except for the base of the Crassicosta Zone, which is directly dated in the Queen Charlotte Islands (Pálfy et al., 1997). Ammonoid provinciality warrants the use of the North American regional ammonoid zonal scale (Fig. 1A), which is correlated with the northwest European standard chronostratigraphy following Smith et al. (1988) and Jakobs et al. (1994) (Fig. 1B). Calculated best estimates for initial zonal boundaries are as follows (Fig. 1A): Kunae Zone (early-late Pliensbachian boundary), $185.7+0.5$ /-0.6; Carlottense Zone, 184.1 +1.2/-1.6 Ma; Kanense Zone (PliensbachianToarcian boundary), 183.6+1.7/-1.1 Ma; Planulata Zone, 182.0 +3.3/-1.8 Ma; Crassicosta Zone, $181.4 \pm 1.2 \mathrm{Ma}$.

\section{TOARCIAN STABLE ISOTOPE STRATIGRAPHY}

Recognition of a prominent positive $\delta^{13} \mathrm{C}$ excursion in the Falciferum Zone, along with widespread organic-rich facies, is the basis for defining an early Toarcian oceanic anoxic event (Jenkyns, 1988). Originally the $\delta^{13} \mathrm{C}$ maximum was thought to be restricted to the Falciferum Zone, but in several Tethyan sections, the rise of $\delta^{13} \mathrm{C}$ begins in the Tenuicostatum Zone (Jenkyns et al., 1991; Jiménez et al., 1996; E. Morettini, 1999, personal commun.) (Fig. 1G). Organic-rich black shale deposition is also known in the Tenuicostatum Zone in Spain and Italy (Jiménez et al., 1996; E. Morettini, 1999, personal commun.), and manganese-rich deposits are widespread in the Tenuicostatum to Falciferum zones (Jenkyns et al., 1991). Jenkyns and Clayton (1997) argued that such temporal differences stemmed from correlation problems of the ammonoid biochronology, but it is feasible that environmental changes leading to the widespread oceanic anoxia were gradually developing during the first two chrons of the Toarcian.

A $\delta^{18} \mathrm{O}$ minimum in the Falciferum Zone records a paleotemperature maximum for the Toarcian (Jenkyns and Clayton, 1997). Those authors considered that a correlation with increased $\mathrm{CO}_{2}$ level is a strong possibility supported by low levels of $\delta^{13} \mathrm{C}$ of organic matter. We note that the $\mathrm{CO}_{2}$ in voluminous volcanic outgassing is a possible cause of greenhouse warming. 
TABLE 1. U-Pb ZIRCON DATES FROM BRITISH COLUMBIA USED IN ESTIMATING AGE OF PLIENSBACHIAN AND TOARCIAN ZONAL BOUNDARIES

\begin{tabular}{|c|c|c|c|c|}
\hline \multirow[t]{2}{*}{ Dated rock } & \multirow[t]{2}{*}{ Locality } & \multirow[t]{2}{*}{$\begin{array}{c}\text { U-Pb age } \\
(\mathrm{Ma})^{*}\end{array}$} & \multicolumn{2}{|c|}{$\begin{array}{c}\text { Biochronologic age } \\
\text { (zone or stage) }\end{array}$} \\
\hline & & & Maximum & Minimum \\
\hline Chuchi intrusion & BP Chuchi property & $188.5 \pm 2.5$ & Whiteavesi & Kunae \\
\hline Tuff in Laberge Group & Atlin Lake (East shore) & $187.5 \pm 1.0$ & Whiteavesi & Whiteavesi \\
\hline Tuff in Hazelton Group & Todagin Mtn., Spatsizi area & $185.6+7.3 /-0.6$ & Freboldi & Freboldi \\
\hline Granitoid boulder in Laberge Gr. & Atlin Lake (Sloko Island) & $186.6+0.5 /-1.0^{\dagger}$ & Sinemurian & Kunae \\
\hline Tuff in Laberge Group & Atlin Lake (Copper Island) & $185.8 \pm 0.7$ & Kunae & Kunae \\
\hline Tuff in Hazelton Group & Skinhead Lake & $184.7 \pm 0.9$ & Kunae & Kunae \\
\hline Tuff ("Nordenskiold volcanics") & Whitehorse & $184.1+5.8 /-1.6$ & Kunae & Kunae \\
\hline Eskay porphyry & Eskay Creek, Iskut River area & $184+6 /-1$ & Carlottense & Aalenian \\
\hline McEwan Creek pluton & McEwan Creek, Spatsizi area & $183.2 \pm 0.7$ & Kanense & Planulata \\
\hline Tuff in Hazelton Group & Mt. Brock range, Spatsizi area & $180.4+11.2 /-0.4$ & Kanense & Planulata \\
\hline Tuff in Whiteaves Formation & Yakoun River, Queen Charlotte Is. & $181.4 \pm 1.2$ & Crassicosta & Crassicosta \\
\hline Tuff in Hazelton Group & Julian Lake & $178 \pm 1$ & Yakounensis & Aalenian \\
\hline Eskay thyolite & Eskay Creek anticline, west limb & $175.1 \pm 4.7$ & Yakounensis & Aalenian \\
\hline Eskay rhyolite & Eskay Creek anticline, east limb & $174.1+4.5 /-1.1$ & Yakounensis & Aalenian \\
\hline \multicolumn{5}{|c|}{$\begin{array}{l}\text { Note: References to sources of isotopic ages and their biochronologic constraints are given in Pálfy et al. (2000b). See Figure } \\
1 \text { for ammonoid zones. } \\
* \text { External error quoted at } 2 \sigma \text { level. } \\
\text { Maximum age. }\end{array}$} \\
\hline
\end{tabular}

\section{PLIENSBACHIAN-TOARCIAN} STRONTIUM ISOTOPE STRATIGRAPHY

Temporal variations in the ${ }^{87} \mathrm{Sr} /{ }^{86} \mathrm{Sr}$ ratio of the Early Jurassic oceans were measured by Jones et al. (1994) (Fig. 1H) and refined by McArthur et al. (2000). Following a nearly continuous decline from the Hettangian to the Pliensbachian, the curve reaches a minimum at the PliensbachianToarcian boundary and rises in the Toarcian; the steepest slope is recorded for the Falciferum Zone. It is notable that the major Early Jurassic inflection appears to coincide with the inception of Karoo-Ferrar volcanism. The early Toarcian rise can be related to increased humidity and continental weathering, possibly enhanced by acid rain, under escalating greenhouse conditions triggered by volcanic emissions.

\section{DISCUSSION}

Synchrony and possible causal links between mass extinctions and continental flood basalts have been postulated by several authors (e.g., Rampino and Stothers, 1988; Stothers, 1993; Courtillot, 1994). However, evidence for precise and reliable correlation was tenuous in many cases. A proposed link between the South African flood basalts and the Pliensbachian extinction (Rampino and Stothers, 1988; Stothers, 1993) was based on a fortuitous coincidence near $190 \mathrm{Ma}$ of the anomalously old K-Ar ages and the overestimate of the Pliensbachian-Toarcian boundary age in older time scales. Duncan et al. (1997) compared their ${ }^{40} \mathrm{Ar}-{ }^{39} \mathrm{Ar}$ dating results with the time scale of Gradstein et al. (1994), and suggested that the Karoo volcanism may have contributed to the Toarcian-Aalenian faunal turnover, although the latter does not correspond to an extinction peak. Rampino and Stothers (1988) and Stothers (1993) suggested that the Antarctic flood basalts played a role in a pur- ported Bajocian extinction, but this correlation was based on anomalously young K-Ar ages. Moreover, the Bajocian is not a time of significant extinction (e.g., Benton, 1995).

The two major impediments to establishing synchrony, namely inaccurate dating of mafic igneous rocks and inadequate numeric time scales, are being removed by improved isotopic dating methods, chiefly the U-Pb and ${ }^{40} \mathrm{Ar}-{ }^{39} \mathrm{Ar}$ techniques. Now there is a strong case for a temporal relationship between three of the major mass extinctions and magmatic activity associated with large igneous provinces. Eruption of the Siberian Traps coincided with the end-Permian mass extinction at $251 \mathrm{Ma}$ (e.g., Renne et al., 1995), a volcanic spasm of the Central Atlantic Magmatic Province at $200 \mathrm{Ma}$ (Marzoli et al., 1999), and is coeval with the end-Triassic crisis (Pálfy et al., 2000a), whereas the end-Cretaceous mass extinction occurred at 65 Ma during paroxysmal volcanism of the Deccan Traps (Baksi and Farrar, 1991). As demonstrated here, the synchrony of the Pliensbachian-Toarcian extinction and volcanism of the Karoo-Ferrar large igneous province is now well established at 184-182 Ma. Such temporal coincidence requires consideration of a possible causal linkage.

The end-Pliensbachian reversal and Toarcian increase of the $\mathrm{Sr}$ isotope ratio is suggested to record the onset of Karoo-Ferrar volcanism. A similar inflection occurs in the Late Permian, although it appears to predate slightly the Siberian Traps (Martin and Macdougall, 1995). The formation of the Central Atlantic Magmatic Province around the Triassic-Jurassic boundary coincides with a downturn of the Sr curve. Modeling results suggest that continental flood basalt volcanism could alter seawater chemistry via enhanced weathering and increase of riverine flux (Martin and Macdougall, 1995). We specu- late that changes of opposite sense across the Triassic-Jurassic boundary may reflect the equatorial latitude of the Central Atlantic Magmatic Province (vs. the middle- to high-latitude Siberian Traps and Karoo-Ferrar province), whereby basalt weathering exerts greater influence on the oceanic Sr budget and explains a shift toward less radiogenic values (Taylor and Lasaga, 1999).

The sudden climate and other environmental changes associated with the Karoo-Ferrar volcanism could have triggered the end-Pliensbachian extinction. The early Toarcian sea-level rise may or may not be related to the mantle plume under southern Gondwana and associated tectonic processes, but it would have had significant environmental impact. With intense volcanism sustained for 1-2 m.y., further climate warming occurred (as recorded in the $\delta^{18} \mathrm{O}$ curve). Oceanographic changes induced by coupled effects of warming, transgression, and increased nutrient availability via more intensive weathering generated an oceanic anoxic event that started in the Tenuicostatum Zone. Indication of increasing productivity during the early Toarcian (Vetô et al., 1997), clearly a factor in black shale formation, raises the possibility of volcanically derived iron fertilization of the world ocean (Coale et al., 1996). Peak extinction of marine benthos, observed at the species level in the Falciferum Zone, coincided with maximum spread of anoxic bottom waters. The pulse of flood basalt volcanism likely waned by the time of the end of the Bifrons Zone. Despite several parallels with the end-Permian mass extinction (linked to flood basalt eruption, climate warming, anoxia, and isotopic trends), the Pliensbachian-Toarcian extinction is clearly of much lesser magnitude. Besides the smaller size of the Karoo-Ferrar igneous province, its position at high southern latitude might also explain its less severe effect on the biota. 
Future research should test the possible role of Karoo-Ferrar volcanism in triggering environmental change and concomitant mass extinction by quantitatively modeling the scenarios outlined herein, i.e., the possible effects of volcanic output on the biogeochemical cycles, climate, and seawater $\mathrm{Sr}$ isotope evolution.

\section{ACKNOWLEDGMENTS}

We thank E. Morettini and J. McArthur for discussion and sharing preprints, and P. Renne for advice. Pálfy acknowledges the support of Collegium Budapest and the Hungarian Scientific Research Fund (F23451); Smith was supported by the Natural Science and Engineering Research Council of Canada. We thank P.E. Olsen and an anonymous reviewer for constructive comments.

\section{REFERENCES CITED}

Aberhan, M., and Fürsich, F.T., 1997, Diversity analysis of Lower Jurassic bivalves of the Andean Basin and the Pliensbachian-Toarcian mass extinction: Lethaia, v. 29, p. 181-195.

Baksi, A.K., and Farrar, E., $1991,{ }^{40} \mathrm{Ar} /{ }^{39} \mathrm{Ar}$ dating of the Siberian Traps, USSR: Evaluation of the two major extinction events relative to episodes of flood-basalt volcanism in the USSR and the Deccan Traps, India: Geology, v. 19, p. 461-464.

Benton, M.J., 1995, Diversification and extinction in the history of life: Science, v. 268, p. 52-58.

Coale, K.H., and 18 others, 1996, A massive phytoplankton bloom induced by an ecosystem-scale iron fertilization experiment in the equatorial Pacific Ocean: Nature, v. 383, p. 495-501.

Coffin, M.F., and Eldholm, O., 1994, Large igneous provinces: Crustal structure, dimensions and external consequences: Reviews of Geophysics, v. 32, p. 1-36.

Courtillot, V., 1994, Mass extinctions in the last 300 million years: One impact and seven flood basalts?: Israel Journal of Earth Sciences, v. 43, p. $255-266$.

Duncan, R.A., Hooper, P.R., Rehacek, J., Marsh, J.S., and Duncan, A.R., 1997, The timing and duration of the Karoo igneous event, southern Gondwana: Journal of Geophysical Research, v. 102, p. $18,127-18,138$.

Encarnación, J., Fleming, T.H., Elliot, D.H., and Eales, H., 1996, Synchronous emplacement of Ferrar and Karoo dolerites and the early breakup of Gondwana: Geology, v. 24, p. 535-538.

Fitch, F.J., and Miller, J.A., 1984, Dating Karoo igneous rocks by the conventional $\mathrm{K} / \mathrm{Ar}$ and ${ }^{40} \mathrm{Ar} /{ }^{39} \mathrm{Ar}$ age spectrum methods, in Erlank, A.J., ed., Petrogenesis of the volcanic rocks of the Karoo Province: Geological Society of Africa Special Publication 13, p. 247-266.

Foland, K.A., Fleming, T.H., Heimann, A., and Elliot, D.H., 1993, Potassium-argon dating of finegrained basalts with massive Ar-loss: Application of the ${ }^{40} \mathrm{Ar} /{ }^{39} \mathrm{Ar}$ technique to plagioclase and glass from the Kirkpatrick Basalt, Antarctica: Chemical Geology, v. 107, p. 173-190.

Gradstein, F.M., Agterberg, F.P., Ogg, J.G., Hardenbol, J., van Veen, P., Thierry, J., and Huang, Z., 1994, A Mesozoic time scale: Journal of Geophysical Research, v. 99, p. 24,051-24,074.

Hallam, A., 1986, The Pliensbachian and Tithonian extinction events: Nature, v. 319, p. 765-768.

Hallam, A., 1996, Recovery of the marine fauna in Europe after the end-Triassic and early Toarcian mass extinctions, in Hart, M.B., ed., Biotic recovery from mass extinction events: Geological Society [London] Special Publication 102, p. 231-236.
Hallam, A., 1997, Estimates of the amount and rate of sea-level change across the Rhaetian-Hettangian and Pliensbachian-Toarcian boundaries (latest Triassic to Early Jurassic): Geological Society of London Journal, v. 154, p. 773-779.

Hargraves, R.B., Rehacek, J., and Hooper, P.R., 1997, Paleomagnetism of the Karoo igneous rocks in South Africa: South African Journal of Geology, v. 100, p. 195-212.

Harland, W.B., Armstrong, R.L., Cox, A.V., Craig, L.E., Smith, A.G., and Smith, D.G., 1990, A geologic time scale 1989: Cambridge, UK, Cambridge University Press, $263 \mathrm{p}$.

Heimann, A., Fleming, T.H., Elliot, D.H., and Foland, K.A., 1994, A short interval of Jurassic continental flood basalt volcanism in Antarctica as demonstrated by ${ }^{40} \mathrm{Ar} /{ }^{39} \mathrm{Ar}$ geochronology: Earth and Planetary Science Letters, v. 121, p. 19-41.

Hori, S.R., 1993, Toarcian oceanic event in deep-sea sediments: Geological Survey of Japan Bulletin, v. 44 , p. $555-570$.

Jakobs, G.K., Smith, P.L., and Tipper, H.W., 1994, An ammonite zonation for the Toarcian (Lower Jurassic) of the North American Cordillera: Canadian Journal of Earth Sciences, v. 31, p. 919-942.

Jenkyns, H.C., 1988, The early Toarcian (Jurassic) anoxic event: Stratigraphic, sedimentary, and geochemical evidence: American Journal of Science, v. 288, p. 101-151.

Jenkyns, H.C., and Clayton, C., 1997, Lower Jurassic epicontinental carbonates and mudstones from England and Wales: Chemostratigraphic signals and the early Toarcian anoxic event: Sedimentology, v. 44, p. 687-706.

Jenkyns, H.C., Géczy, B., and Marshall, J.D., 1991, Jurassic manganese carbonates of central Europe and the early Toarcian anoxic event: Journal of Geology, v. 99, p. 137-149.

Jiménez, A.P., Jiménez de Cisneros, C., Rivas, P., and Vera, J.A., 1996, The early Toarcian anoxic event in the westernmost Tethys (Subbetic); paleogeographic and paleobiogeographic significance: Journal of Geology, v. 104, p. 399-416.

Jones, C.E., Jenkyns, H.C., and Hesselbo, S.P., 1994, Strontium isotopes in Early Jurassic seawater: Geochimica et Cosmochimica Acta, v. 58 , p. $1285-1301$

Little, C.T.S., 1996, The Pliensbachian-Toarcian (Lower Jurassic) extinction event, in Ryder, G., et al., eds., The Cretaceous-Tertiary event and other catastrophes in Earth history: Geological Society of America Special Paper 307, p. 505-512.

Little, C.T.S., and Benton, M.J., 1995, Early Jurassic mass extinction: A global long-term event: Geology, v. 23, p. 495-498.

Martin, E.E., and Macdougall, J.D., 1995, Sr and Nd isotopes at the Permian/Triassic boundary: A record of climate change: Chemical Geology, v. 125 , p. $73-100$.

Marzoli, A., Renne, P.R., Piccirillo, E.M., Ernesto, M., Bellieni, G., and De Min, A., 1999, Extensive 200-million-year-old continental flood basalts of the Central Atlantic magmatic province: Science, v. 284, p. 616-618.

McArthur, J.M., Donovan, D.T., Thirlwall, M.F., Fouke, B.W., and Mattey, D., 2000, Strontium isotope profile of the early Toarcian (Jurassic) oceanic anoxic event, the duration of ammonite biozones, and belemnite paleotemperatures: Earth and Planetary Science Letters (in press).
Minor, D.R., and Mukasa, S.B., 1997, Zircon U-Pb and hornblende ${ }^{40} \mathrm{Ar}-{ }^{39} \mathrm{Ar}$ ages for the Dufek layered mafic intrusion, Antarctica: Implications for the age of the Ferrar large igneous province: Geochimica et Cosmochimica Acta, v. 61, p. 2497-2504.

Pálfy, J., Parrish, R.R., and Smith, P.L., 1997, A U-Pb age from the Toarcian (Lower Jurassic) and its use for time scale calibration through error analysis of biochronologic dating: Earth and Planetary Science Letters, v. 146, p. 659-675.

Pálfy, J., Mortensen, J.K., Carter, E.S., Smith, P.L., Friedman, R.M., and Tipper, H.W., 2000a, Timing the end-Triassic mass extinction: First on land, then in the sea?: Geology, v. 28, p. 39-42.

Pálfy, J., Smith, P.L., and Mortensen, J.K., 2000b, A $\mathrm{U}-\mathrm{Pb}$ and ${ }^{40} \mathrm{Ar}-{ }^{39} \mathrm{Ar}$ time scale for the Jurassic: Canadian Journal of Earth Sciences (in press).

Rampino, M.R., and Stothers, R.B., 1988, Flood basalt volcanism during the last 250 million years: Science, v. 241, p. 663-667.

Raup, D.M., and Sepkoski, J.J., Jr., 1984, Periodicity of extinctions in the geologic past: National Academy of Science Proceedings, v. 81, p. 801-805.

Renne, P.R., Zichao, Z., Richards, M.A., Black, M.T., and Basu, A.R., 1995, Synchrony and causal relations between Permian-Triassic boundary crises and Siberian flood volcanism: Science, v. 269 , p. 1413-1416.

Renne, P.R., Swisher, C.C., Deino, A.L., Karner, D.B., Owens, T.L., and DePaolo, D.J., 1998, Intercalibration of standards, absolute ages and uncertainties in ${ }^{40} \mathrm{Ar} /{ }^{39} \mathrm{Ar}$ dating: Chemical Geology, v. 145 , p. $117-152$.

Smith, P.L., Tipper, H.W., Taylor, D.G., and Guex, J., 1988, An ammonite zonation for the Lower Jurassic of Canada and the United States: The Pliensbachian: Canadian Journal of Earth Sciences, v. 25, p. 1503-1523.

Stothers, R.B., 1993, Flood basalts and extinction events: Geophysical Research Letters, v. 20, p. 1399-1402.

Taylor, A.S., and Lasaga, A.C., 1999, The role of basalt weathering in the Sr isotope budget of the oceans: Chemical Geology, v. 161, p. 199-214.

Vető, I., Demény, A., Hertelendi, E., and Hetényi, M., 1997, Estimation of primary productivity in the Toarcian Tethys-A novel approach based on TOC, reduced sulphur and manganese contents: Palaeogeography, Palaeoclimatology, Palaeoecology, v. 132, p. 355-371.

Vörös, A., 1993, Jurassic brachiopods from the Bakony Mts. (Hungary): Global and local effects on changing diversity, in Pálfy, J., and Vörös, A., eds., Mesozoic brachiopods of Alpine Europe: Budapest, Hungarian Geological Society, p. 179-187.

Manuscript received January 10, 2000

Revised manuscript received May 18, 2000

Manuscript accepted May 23, 2000 